\title{
KARAKTERISTIK FISIK DAN AKTIVITAS ANTIOKSIDAN SEDIAAN MASKER GEL PEEL OFF EKSTRAK METANOL DAUN ECENG GONDOK
}

\author{
Nabila Ukhty ${ }^{*}$, Ikhsanul Khairi, Tika Wulan Dari \\ Program Studi Perikanan, Fakultas Perikanan dan Ilmu Kelautan, Universitas Teuku Umar
}

Diterima: 16 September 2021/Disetujui: 29 Desember 2021

*Korespondensi: nabilaukhty@utu.ac.id

Cara sitasi: Ukhty N, Khairi I, Dari TW. 2021. Karakteristik fisik dan aktivitas antioksidan sediaan masker gel peel off ekstrak metanol daun eceng gondok. Jurnal Pengolahan Hasil Perikanan Indonesia. 24(3): 416-424.

\begin{abstract}
Abstrak
Masker wajah gel peel off merupakan salah satu jenis sediaan masker wajah yang dapat meningkatkan kenyamanan penggunaan dan diharapkan dapat meningkatkan aktivitas antioksidan pada kulit. Masker tersebut berbentuk pasta, dengan tekstur yang kental. Eceng gondok (Eichhornia crassipes) merupakan tumbuhan air yang hidup secara liar di kawasan perairan Aceh Barat. Tujuan dari penelitian ini adalah untuk menentukan rendemen ektrak kasar metanol daun eceng gondok, formulasi terbaik sediaan masker wajah gel peel off ekstrak kasar metanol daun eceng gondok berdasarkan karakteristik fisik sediaan masker dan aktivitas antioksidan formulasi terbaik. Metode ekstraksi yang digunakan yaitu maserasi menggunakan metanol sebagai pelarut. Perbedaan komposisi ekstrak yang digunakan yaitu konsentrasi $0 \%, 2 \%, 4 \%$ dan 6\%. Eksplorasi senyawa aktif pada ekstrak kasar menggunakan uji fitokimia. Penilaian karakteristik fisik sediaan masker meliputi uji organoleptis, homogenitas, daya lekat, daya sebar, $\mathrm{pH}$, dan waktu mengering, Berdasarkan hasil penelitian diperoleh rendemen ekstrak kasar metanol daun eceng gondok sebesar 8,9\% dari bobot simplisia. Ekstrak kasar tersebut mengandung senyawa flavonoid, tannin, steroid, terpenoid, dan saponin. Formulasi ekstrak 6\% eceng gondok pembuatan masker gel peel off merupakan sediaan masker terbaik dengan penilaian homogenitasnya stabil dan tidak ada perubahan, daya lekat selama 5,30 detik, daya sebar 5,9 cm, pH 6,4, serta mengering dalam waktu 27,48 menit. Sediaan masker F3 memiliki daya hambat DPPH (\%inhibisi) sebesar 76,54\%.
\end{abstract}

Kata Kunci: Eichhornia crassipes, ekstraksi, formulasi, gel peel off

\section{Physical Characteristics Gel Peel Off Mask from Methanol Crude Extracts of Water Hyacinths}

Gel peel off face mask is one type of facial mask that can increase the comfort of use and is expected to increase antioxidant activity on the skin. The mask is shaped like a paste, with a thick texture. Water hyacinths (Eichhornia crassipes) is an aquatic plant that lives wild in the waters of West Aceh. The purpose of this study was to determine the yield of methanolic crude extract of water hyacinths's leaves and to find out the best formulation of gel peel off face mask from methanol crude extract of water hyacinths's leaf based on the physical characteristics of the mask. The extraction method used was maceration using methanol as a solvent. The differences in the composition of the extracts used were concentrations of $0 \%, 2 \%, 4 \%$ and $6 \%$. Exploration of bioactive compounds in crude extract using phytochemical test. Assessment of the physical characteristics of the mask preparation included organoleptic tests, homogeneity, adhesion, dispersibility, $\mathrm{pH}$, and drying time. The crude extract contains flavonoid compounds, tannins, steroids, terpenoids, and saponins. Formulation of $6 \%$ water hyacinths extract for making gel peel off masks was the best mask with an assessment of its homogeneity being stable and no change, adhesion for 5.30 seconds, dispersion of 5.9 $\mathrm{cm}$, pH 6.4, and drying in 27.48 minutes. The formula has DPPH inhibition (\% inhibition) of $76.54 \%$.

Keywords: Eichhornia crassipes, extraction, facial mask, gel peel off 


\section{PENDAHULUAN}

Perairan estuaria Aceh Barat salah satu kawasan yang banyak ditumbuhi oleh tumbuhan eceng gondok. Tingginya pertumbuhan eceng gondok tidak sejalan dengan pemanfaatan tumbuhan tersebut, sehingga menjadi tumbuhan yang merugikan untuk ekosistem. Menurut Koes (2010) pemberantasan tanaman ini dinilai juga tidak efektif karena tingkat pertumbuhannya lebih cepat dari pembuangannya, sehingga diperlukan pemanfaatan yang lebih optimal. Secara empiris akar tumbuhan ini baru dimanfaatkan sebagai bahan pembuatan furnitur rumah tangga oleh masyarakat Aceh Barat.

Tumbuhan eceng gondok diketahui mengandung senyawa aktif yang dapat dimanfaatkan untuk produk kesehatan. Shanab et al. (2010) menginformasikan bahwa adanya senyawa metabolit sekunder pada ekstrak metanol daun eceng gondok di antaranya alkaloid, komponen fenol, dan terpenoid. Nyananyo et al. (2007) menginformasikan bahwa eceng gondok mengandung senyawa flavonoid (luteolin, apigenin, tricin, krisoeriol, kaemferol, azaeleatin, gossypetin, dan orientin), asam amino fosfor, protein, komponen organik, dan sianida. Seluruh senyawa-senyawa tersebut membuktikan bahwa daun eceng gondok memiliki potensi untuk dimanfaatkan dalam produk kesehatan, salah satunya yaitu produk kesehatan kulit.

Kosmetik adalah bahan atau campuran bahan yang digunakan pada permukaan kulit manusia yang bertujuan untuk membersihkan, memelihara, dan menambah daya tarik. Kosmetik tidak termasuk ke dalam golongan obat-obatan. Salah satu contoh kosmetik adalah masker wajah. Masker gel peel off merupakan salah satu masker wajah dengan sediaan berbentuk gel, yang kemudian akan kering dan membentuk lapisan film yang elastis pada permukaan kulit dan mudah dalam pemakaiannya karena tidak perlu dibilas. Formulasi masker peel off menggunakan polivinil alkohol (PVA) sebagai bahan pembentuk film (Sutriningsih dan Astuti 2017). Penggunaan masker gel peel off mampu meningkatkan kelembapan kulit serta efek pada bagian epitel kulit karena oklusifitas lapisan polimer yang terbentuk (Shai et al. 2009; Vierra 2009; Berighs et al. 2013).

Pembuatan masker wajah peel off dari bahan alam yaitu ekstrak daun eceng gondok (Eichhornia crassipes). Tujuan dari penelitian ini adalah untuk menentukan rendemen ekstrak kasar metanol daun eceng gondok, kandungan senyawa aktif ekstrak daun eceng gondok, sediaan dengan formulasi terbaik masker wajah gel peel off ekstrak kasar metanol daun eceng gondok berdasarkan karakteristik fisik sediaan masker, dan aktivitas antioksidan menggunakan metode DPPH pada formulasi terbaik masker gel peel off.

\section{BAHAN DAN METODE Bahan dan Alat}

Bahan utama yang digunakan pada penelitian ini yaitu daun eceng gondok yang diperoleh dari perairan estuaria Desa Suak Ribe, Kabupaten Aceh Barat. Bahan-bahan pendukung yang digunakan terdiri dari pelarut metanol (Merck), bahan formulasi masker gel peel off yang terdiri dari etanol 96\% (Merck), polivinil alkohol (PVA) (Sigma), hidroksipropil metil selulose (HPMC), gliserin (Wilmar), nipagin (teknis), nipasol (teknis), dan akuades. Reagen yang digunakan pada uji fitokimia terdiri dari akuades, $\mathrm{FeCl}_{3}$ $1 \%$ (Merck), asam sulfat $\left(\mathrm{H}_{2} \mathrm{SO}_{4}\right)$ (Merck), dan pereaksi shinoda.

Alat yang digunakan pada penelitian ini di antaranya seperangkat alat gelas (Pyrex), timbangan digital (Metler teledo), viskometer (Brookfield Manifold type DVII), evaporator putar (Quickfit), neraca analisis digital (Ohauss), pH meter (Hanna), jam rekam (stopwatch), dan spektrofotometer UV-VIS (Hitachi U 2000).

\section{Metode Penelitian}

Penelitian ini menggunakan metode eksperimen yang terdiri daribeberapa tahapan, yaitu preparasi bahan baku, ekstraksi daun eceng gondok, pengujian fitokimia eksrak kasar eceng gondok, formulasi masker gel peel off, analisis karakteristik fisik sediaan masker (penilaian organolpetis, homogenitas, daya 
lekat, daya sebar, $\mathrm{pH}$, waktu mengering) dan pengujian aktivitas antioksidan menggunakan metode DPPH.

\section{Ekstraksi daun eceng gondok}

Simplisia daun eceng gondok diekstraksi menggunakan metode maserasi dengan pelarut metanol selama $3 \times 24$ jam mengacu pada (Handa et al. 2008; Azwanida 2015) Pergantian pelarut dilakukan setiap 1x24 jam untuk mengoptimalkan proses ekstraksi. Filtrat yang diperoleh kemudian dipekatkan dengan cara evaporasi menggunakan evaporator putar. Hasil evaporasi berupa ekstrak kasar berbentuk pasta, kemudian ditimbang sebagai data perhitungan rendemen ekstrak kasar metanol daun eceng gondok.

Perhitungan rendemen:

Rendemen $(\%)=\frac{\text { Berat ekstrak } \text { kasar }}{\text { Berat simplisia }} \times 100 \%$

\section{Uji fitokimia (Harborne Budiman et al. (2017)}

(1987);

Eksplorasi kandungan senyawa aktif pada ekstrak daun eceng gondok menggunakan uji fitokimia yang terdiri dari flavonoid, tannin, steroid, terpenoid dan saponin. Pengujian fitokimia mengaju pada Harborne (1987); Budiman et al. (2017).

\section{Formulasi masker gel peel off (Purwati dan Verryanti 2016)}

Tahapan formulasi sediaan masker terdiri dari empat perlakuan yang berbeda. Perbedaan formulasi terletak pada jumlah ekstrak metanol daun eceng gondok. Formulasi sediaan masker gel peel off mengacu pada penelitian (Purwati dan Verryanti 2016) yang dimodifikasi. Formulasi pembuatan masker dapat dilihat pada Table 1.

\section{Karakteristik fisik sediaan masker gel peel off}

Pengujian karakteristik fisik sediaan masker gel peel off dilakukan pada penyimpanan hari ke 0 dan penyimpanan hari ke 40. Tujuannya untuk melihat apakah terjadi perubahan pada sediaan masker selama masa penyimpanan 40 hari.

\section{Uji organoleptik (SNI 01-2346-2006)}

Pengujian organoleptik merupakan cara pengujian menggunakan indra manusia sebagai alat utama untuk menilai mutu produk, bau, rasa, dan konsistensi/tekstur serta beberapa faktor lain yang diperlukan untuk menilai produk.

Uji homogenitas (Saryanti et al. 2019)

Sejumlah $0,1 \mathrm{~g}$ sediaan dioleskan pada kaca transparan, diamati apakah terdapat bagian yang tidak tercampurkan dengan baik.

\section{Uji pH (Luthfiyana et al. 2019)}

Nilai $\mathrm{pH}$ diukur menggunakan $\mathrm{pH}$ meter pada masing-masing formula selama masa penyimpanan empat minggu di suhu ruang. Pengujian $\mathrm{pH}$ dilakukan dengan cara elektroda dibersihkan menggunakan akuades kemudian dicelupkan ke dalam sediaan masker yang sudah diencerkan hingga 10

Table 1 Formulation of gel peel off mask from water hyacinths extract

\begin{tabular}{lrrrr}
\hline \multirow{2}{*}{ Ingredients } & \multicolumn{4}{c}{ Concentration (\%w/w) } \\
\cline { 2 - 5 } \multicolumn{1}{c}{} & \multicolumn{1}{c}{ F0 } & \multicolumn{1}{c}{ FI } & \multicolumn{1}{c}{ FII } & \multicolumn{1}{c}{ FIII } \\
\hline Water hyacinths extract & - & 2.0 & 4.0 & 6.0 \\
PVA & 10.0 & 10.0 & 10.0 & 10.0 \\
HPMC & 5.0 & 5.0 & 5.0 & 5.0 \\
Gliycerin & 15.0 & 15.0 & 15.0 & 15.0 \\
Nipagin & 0.20 & 0.20 & 0.20 & 0.20 \\
Nipasol & 0.10 & 0.10 & 0.10 & 0.10 \\
Ethanol 96\% & 15.0 & 15.0 & 15.0 & 15.0 \\
Aquadest add & 100.0 & 100.0 & 100.0 & 100.0 \\
\hline
\end{tabular}


mL. Nilai $\mathrm{pH}$ yang muncul pada $\mathrm{pH}$ meter kemudian dicatat.

\section{Uji daya lekat (Rohmani dan Dian 2018)}

Sejumlah $500 \mathrm{mg}$ sediaan diletakkan pada kaca objek yang ditutup dengan kaca objek lain, diberi beban $100 \mathrm{~g}$ selama 5 menit. Setelah itu, kaca objek dipasangkan pada alat uji dan dilakukan pengukuran waktu daya lekat yang dimulai saat beban pada alat uji dilepas hingga lepasnya kedua kaca objek.

\section{Uji daya sebar (Saryanti et al. 2019)}

Sejumlah $0,5 \mathrm{~g}$ sediaan diletakkan pada bagian tengah cawan petri dan didiamkan selama 1 menit. Kemudian diukur penyebarannya pada tiga sisi dengan menggunakan penggaris. Pengukuran diulang dengan pemberian beban $50 \mathrm{~g}$ dan $100 \mathrm{~g}$.

\section{Uji waktu mengering (Luthfiyana et al. 2019)}

Sejumlah $1 \mathrm{~g}$ sediaan dioleskan pada kulit lengan, kemudian dihitung waktu mengering gel hingga membentuk lapisan film dari masker gel peel off menggunakan jam rekam.

\section{Pengujian daya hambat radikal bebas DPPH (Molyneux 2004)}

Metode pengujian daya hambat radikal bebas didasarkan pada kemampuan sampel yang digunakan dalam mereduksiradikalbebas stabil yaitu DPPH. Persentase penghambatan aktivitas radikal bebas diperoleh dari nilai absorbansi sampel. Sampel sediaan diambil sebanyak $1 \mathrm{~g}$ kemudian ditambahkan 100 $\mathrm{mL}$ metanol p.a. Sampel dikocok dengan cepat kurang lebih 5 menit. Kemudian hasil pengocokan disaring dan ditampung filtratnya. Selanjutnya diambil sebanyak $1 \mathrm{~mL}$ larutan sampel dan ditambahkan $1 \mathrm{~mL}$ DPPH dan $3 \mathrm{~mL}$ metanol p.a lalu dihomogenkan. Larutan uji dan larutan blangko diinkubasi pada suhu $37^{\circ} \mathrm{C}$ selama 30 menit. Serapan larutan uji diukur dengan spektrofotometer UV-Vis pada panjang gelombang $517 \mathrm{~nm}$. \% inhibisi dapat dihitung menggunakan rumus :

$\%$ inhibisi $=\frac{\text { Serapan kontrol }- \text { serapan sampel }}{\text { Serapan kontrol }} \times 100 \%$

\section{HASIL DAN PEMBAHASAN Rendemen}

Perhitungan rendemen dilakukan pada bobot simplisia dan juga bobot ekstrak kasar metanol daun eceng gondok. Perhitungan ini bertujuan untuk melihat seberapa banyak senyawa aktif yang dapat dipisahkan oleh pelarut dari bahan utama (simplisia).

Rendemen simplisia menunjukkan nilai 10\%. Hal ini menunjukkan bahwa kadar air pada daun eceng gondok mencapai 90\% dari bobot total daun. Kadar air berkurang akibat adanya proses pengeringan daun segar hingga menjadi simplisia. Rendemen ekstrak kasar metanol daun eceng gondok jika dihitung dari bobot daun segar sebesar $0,89 \%$, sedangkan jika dihitung dari bobot simplisia sebesar $8,9 \%$. Nilai rendemen ekstrak ini menunjukkan banyaknya senyawa yang terikat dengan pelarut metanol karena mempunyai sifat yang sama seperti pelarutnya. Pelarut metanol juga diketahui sebagai pelarut polar yang memilki sifat universal yaitu dapat menarik dan mengikat sebagian besar senyawa yang bersifat polar maupun nonpolar pada sampel (Salamah dan Widyasari 2015).

\section{Kandungan Senyawa Aktif Ekstrak Kasar Metanol Daun Eceng Gondok}

Tahapan eksplorasi senyawa aktif dilakukan melalui uji fitokimia. Kandungan senyawa aktif yang diamati saat melakukan uji fitokimia pada daun eceng gondok.

Ekstrak kasar metanol daun eceng gondok diketahui mengandung senyawa flavonoid, tanin, steroid, terpenoid, dan saponin. Hal ini membuktikan bahwa ekstrak kasar daun eceng gondok berpotensi untuk dikembangkan sebagai bahan dasar pembuatan kosmetik, pangan fungsional dan obat-obatan. Senyawa aktif pada ekstrak kasar metanol juga diduga kuat memiliki aktivitas antioksidan. Hal ini sesuai dengan pernyataan Darusman et al. (2011) bahwa senyawa aktif adalah zat yang menunjukkan aktivitas biologis seperti antioksidan.

\section{Karakteristik Fisik Masker Gel Peel Off}

Sediaan masker gel peel off dibuat dalam empat formulasi yang berbeda yaitu F0, FI, 
FII, dan FIII. Perbedaan masing-masing sediaan terletak pada jumlah ekstrak kasar daun eceng gondok yang ditambahkan. Keempat sediaan masker gel peel off ekstrak daun eceng gondok dapat dilihat pada Figure 1 .

\section{Penilaian organoleptik}

Penilaian organolpetik dilakukan oleh peneliti secara mandiri. Penilaian organoleptik pada sediaan masker dilakukan pada penyimpanan hari ke-0 dan setelah penyimpanan hari ke-40. Hasil pengamatan organoleptik sediaan masker dapat dilihat pada Table 2.

Sediaan masker gel peel off ekstrak daun eceng gondok keempat formulasi tidak mengalami perubahan setelah penyimpanan 40 hari baik dari segi warna, bau, dan bentuk konsistensi sediaan. Penambahan HPMC dalam formulasi dapat menjaga kestabilan sediaan. Menurut Rowe et al. (2009) HPMC adalah bahan pengegel (gelling agent) yang bersifat hidrofilik, sangat stabil pada kondisi asam dan basa yaitu pada pH 3 hingga 11 dengan sifat viskositas yang stabil selama penyimpanan waktu yang panjang. Dalam penelitian ini tidak terdapat perbedaan jumlah HPMC pada tiap formulasi, sehingga diduga perbedaan konsistensi dipengaruhi oleh jumlah ekstrak daun eceng gondok yang digunakan. Banyaknya jumlah ekstrak yang digunakan harus disesuaikan dengan jumlah bahan tambahan lainnya sehingga diperoleh konsistensi yang optimal. Perbedaan konsistensi sediaan masker dipengaruhi oleh banyaknya jumlah ekstrak yang ditambahkan. Ekstrak kasar yang diperoleh dari daun eceng gondok berbentuk pasta, sehingga memengaruhi sediaan masker.

\section{Homogenitas}

Pengujian

homogenitas sediaan dilakukan untuk melihat efektivitas formulasi sediaan yang diamati merata atau tidaknya pencampuran bahan-bahan yang digunakan pada pembuatan masker saat dioleskan. Hasil pengujian homogenitas disajikan pada Figure 2 dan Table 3.

Figure 2 menunjukkan sediaan masker gel peel off ekstrak daun eceng gondok homogen, hal ini terlihat dari tidak adanya

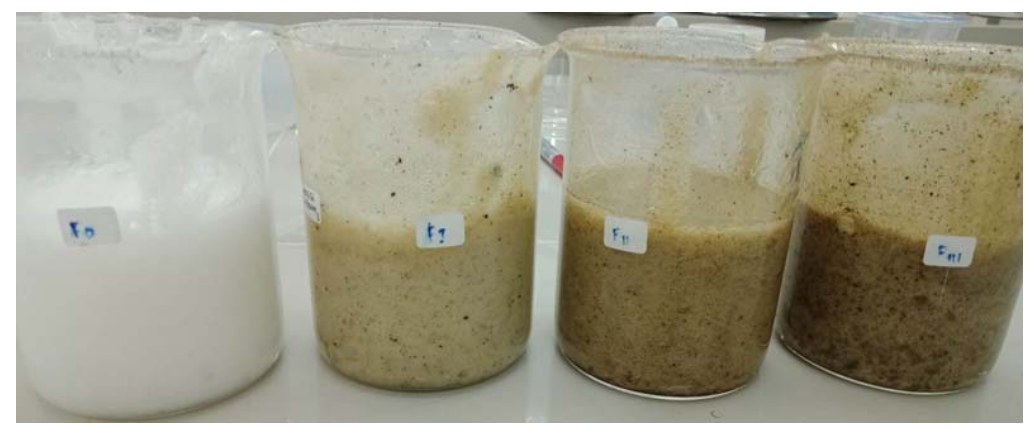

Figure $1 \mathrm{Gel}$ peel off masks of water hyacinths leaves

Table 2 Organoleptics characteristics of gel peel off mask from water hyacinths extract

\begin{tabular}{|c|c|c|c|c|c|c|c|c|}
\hline \multirow{3}{*}{ Characteristics } & \multicolumn{2}{|c|}{ F0 } & \multicolumn{2}{|c|}{ FI } & \multicolumn{2}{|c|}{ FII } & \multicolumn{2}{|c|}{ FIII } \\
\hline & \multicolumn{8}{|c|}{ Days } \\
\hline & 0 & 40 & 0 & 40 & 0 & 40 & 0 & 40 \\
\hline Colour & White & White & $\begin{array}{l}\text { Light } \\
\text { brown }\end{array}$ & $\begin{array}{l}\text { Light } \\
\text { brown }\end{array}$ & Brown & Brown & $\begin{array}{l}\text { Dark } \\
\text { brown }\end{array}$ & $\begin{array}{l}\text { Dark } \\
\text { brown }\end{array}$ \\
\hline Aroma & $\begin{array}{l}\text { Base scent } \\
\text { (PVA) }\end{array}$ & $\begin{array}{l}\text { Base scent } \\
\text { (PVA) }\end{array}$ & $\begin{array}{l}\text { Leaf } \\
\text { scent }\end{array}$ & $\begin{array}{l}\text { Leaf } \\
\text { scent }\end{array}$ & $\begin{array}{l}\text { Leaf } \\
\text { scent }\end{array}$ & $\begin{array}{l}\text { Leaf } \\
\text { scent }\end{array}$ & Leaf scent & $\begin{array}{l}\text { Leaf } \\
\text { scent }\end{array}$ \\
\hline Concistency & Thick & Thick & Thick & Thick & Thick & Thick & $\begin{array}{l}\text { Very } \\
\text { thick }\end{array}$ & $\begin{array}{l}\text { Very } \\
\text { thick }\end{array}$ \\
\hline
\end{tabular}


gumpalan bahan dan perbedaan warna pada olesan di kaca objek transparan. Homogenitas pada suatu formulasi menunjukaan bahwa antara basis yang digunakan dan zat aktif dapat bercampur dengan sempurna (Juwita et al. 2013). Syarat bahan-bahan yang digunakan dalam formulasi sediaan harus dapat terdispersi secara merata sehingga tidak membentuk gumpalan (Purwati dan Verryanti 2016).

\section{Daya lekat}

Kemampuan masker peel off untuk melekat pada kulit dapat diuji melalui perhitungan waktu daya lekat. Daya lekat yang baik untuk sediaan yaitu lebih dari empat detik (santi dan Kusmiyarsih 2011).
Hasil pengujian daya lekat sediaan masker dapat dilihat pada Table 3.

Formula FIII merupakan formula dengan konsistensi paling kental. Semakin besar daya lekat maka absorbsinya semakin besar karena ikatan yang terjadi antara masker gel peel off dengan kulit akan semakin lama (Syam et al. 2021). Perbedaan daya lekat masker gel peel off karena semakin besar konsentrasi ekstrak, maka vsikositas atau kekentalan masker gel peel off semakin besar. Adanya penambahan ekstrak daun eceng gondok dalam formula memengaruhi kemampuan daya lekat gel yaitu bentuk konsistensi dari sediaan masker yang semakin kental sehingga memengaruhi waktu daya lekat lebih lama. Hal ini diduga bahwa ekstrak daun eceng gondok dapat

Table 3 Physical properties of gel peel off mask from water hyacinths extract

\begin{tabular}{|c|c|c|c|c|c|c|}
\hline \multirow{2}{*}{$\begin{array}{l}\text { Physical } \\
\text { properties }\end{array}$} & \multirow{2}{*}{ Day } & \multirow{2}{*}{$\begin{array}{l}\text { Load } \\
\text { weight } \\
(\mathrm{g})\end{array}$} & \multicolumn{4}{|c|}{ Formulation } \\
\hline & & & F0 & FI & FII & FIII \\
\hline \multirow{2}{*}{ Homogeneity } & 0 & - & homogenous & homogenous & homogenous & homogenous \\
\hline & 40 & - & homogenous & homogenous & homogenous & homogenous \\
\hline \multirow{3}{*}{$\begin{array}{l}\text { Adhesion } \\
\text { (second) }\end{array}$} & 0 & - & 2.30 & 3.10 & 3.20 & 4.24 \\
\hline & 40 & - & 3.20 & 4.20 & 4.38 & 5.30 \\
\hline & 0 & 50 & 7.00 & 5.50 & 6.50 & 5.00 \\
\hline \multirow{3}{*}{$\begin{array}{l}\text { Spreadability } \\
(\mathrm{cm})\end{array}$} & 40 & 100 & 7.00 & 5.50 & 6.50 & 5.00 \\
\hline & 0 & 50 & 8.00 & 6.20 & 7.50 & 5.90 \\
\hline & 40 & 100 & 8.00 & 6.20 & 7.50 & 5.90 \\
\hline \multirow{2}{*}{$\mathrm{pH}$} & 0 & - & 7.00 & 6.00 & 6.10 & 6.40 \\
\hline & 40 & - & 7.00 & 6.00 & 6.10 & 6.40 \\
\hline \multirow{2}{*}{$\begin{array}{l}\text { Dry time } \\
\text { (minute) }\end{array}$} & 0 & - & 28.40 & 28.43 & 28.45 & 28.51 \\
\hline & 40 & - & 27.25 & 27.32 & 27.47 & 27.48 \\
\hline
\end{tabular}

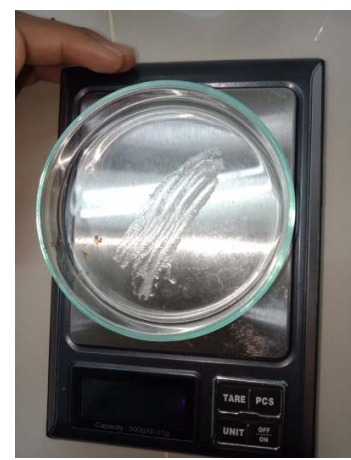

Figure 2 Homogencity of gel peel off mask 
menambah tingkat kekentalan masker sehingga memengaruhi konsistensi sediaan masker dan memengaruhi daya lekat masker. Formula FIII memiliki daya lekat yang lebih lama dibandingkan dengan ketiga formula lainnya.

\section{Daya sebar}

Pengujian daya sebar dilakukan untuk mengetahui luas permukaan kulit yang kontak dengan sediaan masker ketika diaplikasikan. Daya sebar merupakan salah satu syarat yang harus dipenuhi oleh sediaan kosmetik sebagai bukti bahwa produk mudah dioleskan, tidak membutuhkan tekanan yang besar ketika diratakan pada area kulit (Pratama dan Zulkarnain 2015). Hasil Pengujian daya sebar pada sediaan masker gel peel off ekstrak daun eceng gondok dapat dilihat pada Table 3 .

Daya sebar sediaan masker gel peel off ektrak daun eceng gondok berbeda antar setiap formulasi. Sediaan basis masker (F0) memiliki daya sebar yang lebih besar. Semakin banyak jumlah ektrak daun eceng gondok, daya sebar sediaan masker semakin kecil. Hal ini dipengaruhi oleh tingkat kekentalan dari sediaan masker. Menurut Trilestari (2002) perbedaan viskositas atau tingkat kekentalan antar sampel dapat mempengaruhi daya penyebaran. Semakin tinggi nilai viskositas (semakin kental) sediaan maka semakin rendah daya penyebarannya ketika diaplikasikan ke kulit. Pratama dan Zulkarnain (2015) mengatakan bahwa daya sebar yang semakin luas memengaruhi penyebaran senyawa aktif pada kulit lebih merata sehingga senyawa aktif berperan lebih optimal.

Menurut Garg et al. (2002) daya sebar masker gel yang baik berkisar pada $5-7 \mathrm{~cm}$, hal ini menunjukkan pada kisaran tersebut sediaan masker akan lebih mudah dioleskan pada kulit. Formulasi FIII memiliki daya sebar yang lebih konsisten dengan berat beban yang berbeda.

\section{pH}

Pengukuran nilai $\mathrm{pH}$ bertujuan untuk mengetahui apakah sediaan masker bersifat asam atau basa. Produk kosmetik yang diaplikasikan ke kulit memiliki standar nilai $\mathrm{pH}$ yang harus dipenuhi agar tidak membahayakan ketika diaplikasikan. Menurut Rahmawanty et al. (2015) kisaran nilai $\mathrm{pH}$ yang aman untuk produk kesehatan kulit yaitu 4,5-6,5 agar tidak mengiritasi kulit. Nilai pH sediaan masker gel peel off ekstrak daun eceng gondok dapat dilihat pada Table 3. Sediaan formula FI, FII, dan FIII memiliki nilai $\mathrm{pH}$ yang sesuai untuk kulit, Sehingga ketiga formulasi dapat dijadikan sediaan masker berdasarkan nilai $\mathrm{pH}$.

\section{Waktu mengering}

Kecepatan pengeringan suatu sediaan menunjukkan lama waktu yang dibutuhkan untuk mengering hingga terbentuk lapisan film ketika diaplikasikan ke kulit. Menurut Shai et al. (2009) waktu mengering yang baik jika berada pada rentang waktu 15-30 menit setelah diaplikasikan. Hasil pengukuran waktu mengering sediaan masker gel peel off ekstrak daun eceng gondok dapat dilihat pada Table 3 .

Waktu mengering sediaan masker gel peef off ekstrak daun eceng gondok berada pada kisaran 27-29 menit, sehingga masih berada pada kisaran yang diperbolehkan. Waktu mengering dipengaruhi oleh tingkat kekentalan dari suatu sediaan, hal ini disebabkan oleh sifat sediaan yang higroskopis. Menurut Beringhs et al. (2013) sediaan yang bersifat higroskopis dapat menarik dan menahan molekul air sehingga terjadi peningkatan waktu sediaan untuk mengering.

\section{Daya Hambat (\%inhibisi) sediaan Masker gel peel off}

Kekuatan daya hambat terhadap radikal bebas dinyatakan dalam bentuk \%inhibisi. Pengujian ini menggunakan DPPH sebagai radikal bebas yang stabil, sehingga diketahui kemampuan sediaan masker dalam menghambat radikal bebas tersebut. Berdasarkan metode hambatan $\mathrm{DPPH}$, diketahui nilai \%inhibisi sediaan masker gel peel off ekstrak daun eceng gondok yaitu sebesar 76,54\%. Nilai \%inhibisi ini menunjukkan bahwa sediaan masker tersebut mampu menghambat radikal bebas sebanyak $76,54 \%$. 


\section{SIMPULAN}

Rendemen ekstrak daun eceng gondok menggunakan pelarut metanol dihasilkan sebesar 8,9\% dari bobot basah daun. Ekstrak tersebut mengandung senyawa flavonoid, steroid, tanin, terpenoid dan saponin. Formula terbaik berdasarkan karakteristik fisiknya adalah sediaan dengan konsentrasi ekstrak $6 \%$ yaitu dengan nilai daya lekat dan daya sebar yang lebih baik dibandingkan ketiga formula lainnya.

\section{UCAPAN TERIMA KASIH}

Terima kasih kepada Universitas Teuku Umar yang telah mendanai penelitian ini melalui kegiatan hibah internal Universitas dengan nomor surat penugasan 160/UN59/ PT.01.03/2021 Tanggal: 05 Maret 2021.

\section{DAFTAR PUSTAKA}

Azwanida NN. 2015. A review on the extraction methods use in medicinal plants, principle, strength and limitation. Journal of Medical and Aromatic Plants 4 (3): 196

Handa SS, Khanuja SPS, Longo G, Rakesh DD. 2008. Extraction technologies for medicinal and aromatic plants. Italy: United Nations Industrial Development Organization an the International Centre fo Science and High Technology.

Berighs AO, Julia MR, Hellen KS, Rosane MB, dan Dive S. 2013. Green clay and aloevera peel-off facial masks: response surface methodology applied to the formulation design. American Assosiation of Pharmaceutical Scientists. 14(1):445455.

Budiman A, Aulifa DL, Kusuma ASW, Kurniawan IS, Sulastri A. 2017. Peel-off gel formulation from black mulberries (Morus nigra) extract as anti-acne mask. National Journal of Physiology, Pharmacy and Pharmacology. 7(9):1-8.

Garg A, Deepika A, Sanjay G, Anil KS. 2002. Spreading of Semisolid Formulations An Update. Pharmaceutical Technology.

Harborne, JB. 1987. Metode Fitokimia. Bandung(ID):Institut Teknologi Bandung.

Juwita NK, Djajadisastra J, Azizahwati.
2011. Uji penghambatan tirosinase dan stabilitas fisik sediaan krim pemutih yang mengandung ekstrak kulit batang nangka (Artocarpus heterophyllus). Jurnal Ilmu Farmasi. 8(3):17-21.

Luthfiyana N, Nurhikma, Hidayat T. 2019. Karakteristik masker gel peel off dari sediaan bubur rumput laut (Eucheuma cottonii). Jurnal Pengolahan Hasil Perikanan Indonesia. 22(1): 119-127.

Molyneux P. 2004. The use of stable free radical diphenylpicrylhydrazyl (DPPH) for estimating antioksidan activity. Journal of Sciences and Technology. 26(2): 211-219.

Nyananyo BI, Ekeke C, Mensah SI. 2005. The morphology and phytochemistry of water hyacinth, Eichhornia crassipes (Mart) Solms. (Family Pontedericiaceae). Journal of Creativity and Scienctific Studies. 1(2 and 3):20-30.

Pratama WA, Zulkarnain AK. 2015. Uji spf in vitro dan sifat fisik beberapa produk tabir surya yang beredar di pasaran. Majalah farmaseutik. 11(1):275-283.

Purwati, Verryanti. 2016. Aktivitas antioksidan dan evaluasi fisik sediaan masker gel peel off dari ekstrak kulit terung ungu (Solanum melongena 1.). Indonesia Natural Research Pharmaceutical Journal 1(2):10-21.

Rahmawanty D, Yulianti N, Fitriana M. 2015. Formulation and evaluation the peeloff face mask contains quercetin with variations concentrations of gelatin and glycerin. Jurnal Medfarm 12(1):17-2.

Rowe RC, Paul JS, Marian EQ. 2009. Handbook of Pharmaceutical Excipients Sixth Edition. Chicago (US): Pharmaceutical Press.

Salamah N, Widyasari E. 2015. Aktivitas antioksidan ekstrak metanol daun kelengkeng (Euphoria longan (L) Steud.) dengan metode penangkapan radikal 2,2'-difenil-1- pikrilhidrazil. Pharmaciana. 5(1): 25- 34.

Saryanti D, Setiawan I, Safitri RA. 2019. Optimasi sediaan krim M/A dari ekstrak kulit pisang kepok (Musa acuminata L.). Jurnal Riset Kefarmasian Indonesia. 1(3): 225-237.

Shai A, Maibach HI, Baran R. 2009. Handbook 
of Cosmetic Skin Care. Second edition. London : Informa Healthcare.

Shanab SMM, Shalaby EA, Lightfoot DA, dan El-Shemy HA. 2010. Allelopathic effects of water hyacinth (Eichhornia crassipes). PloS ONE. 5(10):1-8.

Sutriningsih, Astuti IW. 2017. Uji antioksidan dan formulasi sediaan masker peel-off dari ekstrak biji alpukat (Persea americana mill.) dengan perbedaan konsentrasi pva (polivinil alkohol). Indonesia Natural Research Pharmaceutical Journal. 1(2): 67-75.

Syam NR, Lestari U, Muhaimin. 2021. Formulasi dan uji sifat fisik masker gel peel off dari minyak sawit murni dengan basis carbomer 940. Indonesian Journal of Pharma Science. 1(1):28-41.

Tranggono, Retno Iswari, Latifah, Fatmah. 2007. Buku pegangan ilmu pengetahuan kosmetik. Jakarta (ID): PT Gramedia Pustaka.

Vierra RP. 2009. Physical and physicochemical stability evaluation of cosmetic formulations containing soybean extract fermented by bifidobacterium animalis. Brazilian journal of Pharmaceutical Sciences. 45(3):515-525.

Wasitaatmadja, Sjarif M. 1997. Penuntun Ilmu Kosmetik Medik. Jakarta:UI Press. 